\title{
Sprawozdanie z Konferencji Naukowej „W przededniu wejścia w życie motu proprio Mitis Iudex Dominus Iesus”
}

Wydane przez papieża Franciszka motu proprio Mitis Iudex Dominus Iesus było tematem przewodnim Konferencji Naukowej zorganizowanej przez Konwent Oficjałów Polskich i Sąd Biskupi Płocki w dniu 26 listopada 2015 roku w Popowie-Letnisku koło Warszawy. Spotkanie zgromadziło wielu przedstawicieli nauki prawa kanonicznego w Polsce, ale także zainteresowanych tematem pracowników kościelnego wymiaru sprawiedliwości oraz studentów i doktorantów.

Konferencję rozpoczął ks. prof. UKSW dr hab. Jan Krajczyński, współorganizator wydarzenia, który w słowach powitania gości i prelegentów stwierdził, że „przepisy prawa z zasady podlegają procesowi rozwoju (...)", wskazując tym samym, że dokument papieża Franciszka nie jest rewolucyjny, a jedynie porządkujący. Pracownik naukowy UKSW w Warszawie podkreślił, że list apostolski Piotra naszych czasów był już tematem wielu konferencji naukowych organizowanych przez różne instytucje naukowe w Polsce, niemniej zagadnienie, ze względu na dość krótki okres vacatio legis, „dopinguje kanonistów i osoby zaangażowane w wymierzanie sprawiedliwości w Kościele do podjęcia wysiłku możliwie dogłębnego poznania nowych przepisów prawa”. Po słowach wprowadzenia Ksiądz Profesor życzył prelegentom i uczestnikom spotkania owocnych obrad.

Pierwszy referat pod tytułem „Zaufanie jako kryterium skutecznej współpracy uczestników procesu o nieważność małżeństwa” wygłosił abp dr hab. Andrzej Dzięga. Metropolita Szczeciński przekazał pozdrowienia od biskupów diecezjalnych Konferencji Episkopatu 
Polski i wspomniał o słowach prof. dr. hab. Wiesława Grudzewskiego, członka korespondenta Polskiej Akademii Nauk, którego pracę „Zaufanie zarządzaniem" miał sposobność recenzować. W przytoczonej publikacji autor stwierdza, że zaufanie można uczynić skutecznym narzędziem zarządzania, Ksiądz Arcybiskup zauważył, że stwierdzenie ekonomistów ma także zastosowanie w procesie o orzeczenie nieważności małżeństwa, kiedy to w procedowaniu wymiar sprawiedliwości ufa świadkom i stronom postępowania. Prelegent kontynuował swój wywód w oparciu o racje teologiczne, wskazując je jako podstawy systemu prawa kanonicznego. Zaufanie Boga do człowieka pojawia się już w Księdze Rodzaju, gdy Stwórca stwierdza, że Adam i Ewa mogą robić wszystko poza spożywaniem owoców z jednego tylko drzewa. Chrystus jest także, zdaniem Księdza Arcybiskupa, tym, który ufa i daje nadzieje. Wymiar teologiczny zaufania ma odzwierciedlenie w normach prawnych, jako przykład prelegent wskazał udzielanie Eucharystii. Szafarz trwa w zaufaniu, że ten kto przychodzi po ten sakrament jest zdolny go przyjąć, trwa w łasce uświęcającej. Prelegent stwierdził wreszcie, że zaufanie trwa w sercu Kościoła, stanowi istotę miłosierdzia, bo nie wszystko człowiek jest w stanie zmarnować. W prawie procesowym zaufanie, zdaniem Księdza Arcybiskupa, jest kluczem interpretacji przepisów. Wskazał, że księga Procesy jest najbardziej prawna i szczegółowa spośród pozostałych ksiąg Kodeksu Prawa Kanonicznego. Stanowi to niewątpliwie ograniczenie zaufania prawodawcy kościelnego, ale wynika to $\mathrm{z}$ faktu, że normy te prowadzą do poznania prawdy. Na koniec swojego wystąpienia Przewodniczący Komisji Prawnej Konferencji Episkopatu Polski postawił postulat, ażeby sędziowie w orzekaniu nieważności małżeństwa, w odkrywaniu prawdy, ufali świadkom i stronom dopóki nie udowodni się czegoś, co przeczy wiarygodności.

Następnie głos zabrał Kierownik Katedry Kościelnego Prawa Administracyjnego UKSW ks. prof. dr hab. Grzegorz Leszczyński, który swoje wystąpienie poświęcił założeniom ogólnym nowego dokumentu papieskiego traktującego o procesie o nieważność małżeństwa. Ksiądz Profesor podkreślił, że naczelną zasadą tego motu proprio jest salus animarum, ponieważ Ojciec Święty Franciszek zauważył, 
że „miłość i miłosierdzie wymagają, aby Kościół jak matka stał się bliski swoim dzieciom, które czują się odłączone”. Za najważniejsze „nowości” Mitis Iudex wykładowca UKSW uznał: jeden wyrok, sędziego jednoosobowego, proces skrócony oraz zmiany w instytucji apelacji. Podkreślił także, że nowe normy zostaną zastosowane jedynie wówczas, gdy poszczególne Konferencje Episkopatu zastosują je w całości, szczególnie doprowadzą do bezpłatności procesów małżeńskich z zaznaczeniem sprawiedliwego i godnego wynagrodzenia dla pracowników kościelnego wymiaru sprawiedliwości.

Kolejnym prelegentem w pierwszej sesji obrad był ks. prof. dr hab. Tomasz Rozkrut z UPJPII w Krakowie, przedstawił on referat pod tytułem „Odpowiedzialność biskupa diecezjalnego, metropolity oraz konferencji biskupów za współczesny proces małżeński”. Charakteryzując zadania i obowiązki biskupów diecezjalnych podkreślił, za dokumentem Franciszka, rolę biskupa jako sędziego ustanowionego dla swoich wiernych. Prelegent odniósł się szczegółowo do postanowień nowego motu proprio, które przypomina biskupom o ich kanonicznych obowiązkach, szczególnie poprzez prowadzenie tzw. processus brevior przez biskupa diecezjalnego. Rola metropolity w trosce o proces małżeński opiera się głównie na kan. $436 \$ 1$, w którym ustawodawca stwierdza, że w diecezjach sufraganalnych metropolicie przysługuje „czuwać nad właściwym zachowaniem wiary oraz dyscypliny kościelnej i powiadamiać Biskupa Rzymskiego o nadużyciach, jeśli jakieś są". Zdaniem prelegenta powyższe zadania metropolita wykonuje głównie poprzez troskę o trybunał metropolitalny, który służy dla diecezji sufraganalnych za trybunał apelacyjny. Wskazując rolę Konferencji Biskupów w odpowiedzialności za proces małżeński Ksiądz Rozkrut przytoczył normy nowego dokumentu papieża Franciszka, w którym czytamy o obowiązku przybliżenia kościelnej posługi sądowej wiernym oraz troski o sprawiedliwe oraz godziwe wynagrodzenie pracowników sądownictwa kościelnego i stworzenie możliwości bezpłatnego prowadzenia procesu o nieważność małżeństwa. Na zakończenie swojego wystąpienia ks. prof. dr hab. Tomasz Rozkrut zaprosił wszystkich uczestników spotkania w Popowie na prezentację komentarza do 
motu proprio Mitis Iudex Dominus Iesus, które odbędzie się w Krakowie 10 grudnia 2015 roku.

Ostatni referat $\mathrm{w}$ pierwszej sesji wygłosił ks. prof. UKSW dr hab. Jan Krajczyński, współorganizator Konferencji, który przygotował referat pod tytułem „Proces zwyczajny”, który traktował o procesie o nieważność małżeństwa w tak zwanej formie zwyczajnej. Prelegent zaznaczył, iż jest to proces jednocześnie specjalny, tzn. przygotowany przez ustawodawcę i nakazany do stosowania przy określonym typie spraw. Referując charakter procesu zwykłego prelegent wskazał jego tryb sądowy oraz to, że postępowanie w pierwszej instancji w tym trybie powinno zakończyć się w ciągu jednego roku, w kolejnej zaś - w sześć miesięcy. Kończąc prelekcję Ksiądz Profesor stwierdził: „Należy żywić nadzieję, że wyzwania jakie stoją przed pracownikami sądów kościelnych, poprzez ich kompetentny osąd, skrupulatne przestrzeganie norm prawa procesowego oraz zgodną $\mathrm{z}$ przepisami prawa kanonicznego ocenę dowodów pozwolą im realizować w Kościele dzieło sprawiedliwości i prawdy".

Następnie ks. prof. KUL dr hab. Piotr Stanisz, przewodniczący sesji, zaprosił wszystkich do dyskusji, zwracając uwagę słuchaczy na częstotliwość pojawiania się w powyższych wystąpieniach słów „odpowiedzialność” oraz „zadania”. Głos zabrał ks. prof. dr hab. Józef Krukowski, który zauważył, że żaden z prelegentów nie spostrzegł, że nowy dokument, mimo iż podkreśla rolę kolegium w orzekaniu nieważności małżeństw, zezwala na udział w jego pracach świeckich. Znamienity Kanonista stwierdził także, że dokument papieża Franciszka posługuje się niefortunnym określeniem laici, co zdaniem Księdza Profesora powinno być zamienione na wyrażenie christifideles laici. Profesor Krukowski wyraził także obawy związane z nieważnością wyroków i rosnącą rolą świeckich. Na ten głos w dyskusji odpowiedział ks. abp Andrzej Dzięga konstatując, że władzę nad sakramentalnym małżeństwem mają świeccy, oni bowiem je zawierają, w związku z czym mądrość Kościoła i antropologia chrześcijańska wskazują, iż to właśnie im należy zaufać w badaniu prawdy o małżeństwie, także w przypadku orzekania nieważności jego zawarcia. Na pytanie Księdza Krukowskiego odpowiedział również ks. Tomasz 
Rozkrut, który zauważył, że nowe motu proprio nie znosi postanowień Instrukcji procesowej Dignitas Connubii, a ta stawia wysokie wymagania świeckim jako kandydatom na sędziów w sądach biskupich.

W dyskusji głos zabrał także ks. prof. dr hab. Wojciech Góralski sygnalizując pewną nieścisłość w referacie ks. prof. dr hab. Grzegorza Leszczyńskiego. Profesor Góralski stwierdził, że asesor nie przedstawia opinii biskupowi, przed którym toczy się processus brevior. Ksiądz Leszczyński stwierdził, że dokument nie dookreśla jak ma wyglądać konsultacja przed wyrokiem biskupa diecezjalnego, a stwierdzenie, $\dot{z} e$ asesor przedstawia opinię o ważności bądź nieważności małżeństwa jest własną interpretacją autora, ponieważ nie pojawiła się interpretacja autentyczna Stolicy Apostolskiej w tym zakresie. Z kolei Ksiądz Krajczyński odpowiadając Profesorowi Góralskiemu zaznaczył, że nowy dokument wskazuje na dwa zupełnie różne zadania instruktora i asesora. Ponownie głos zabrał ks. Góralski zastanawiając się, czy jednomyślność stron wystarczy do uzyskania pełnego dowodu za nieważnością małżeństwa. Ks. Krajczyński stwierdził, że w gestii instruktora procesu jest poinformowanie stron, na przykład w przypadku symulacji zgody małżeńskiej, o charakterze przyznania się symulanta: czy było one wyraźne czy dorozumiane, swobodne, pisemne czy ustne. Rola biskupa skupia się jednak na ocenie wartości dowodowej. Arcybiskup Andrzej Dzięga zaznaczył, że rola instruktora kończy się wraz z przekazaniem akt biskupowi. Tak samo jest w przypadku asesora, którego prawo zobowiązuje do wydania opinii, ale decyzję podejmuje biskup diecezjalny. Zadanie tych osób w procesie polega na spisaniu faktów, a nie ich interpretacji, ponadto, jak zaznaczył Metropolita Szczeciński, zaufanie kieruje w stronę oświadczeń stron, których z natury nie można traktować jako złe, co więcej, należy je traktować poważnie. Interesującym głosem w dyskusji było pytanie ks. Boczko dotyczące skierowania sprawy z procesu zwykłego do skróconego. Czy istnieją jakieś prawne przesłanki do takiej decyzji biskupa? Ks. Krajczyński przywołał opinię ks. Rozkruta, który stwierdził, że nowe normy nie znoszą postanowień Kodeksu Prawa Kanonicznego oraz Instrukcji procesowej Dignitas connubii, w których zmiana trybu możliwa jest, jeśli podczas instrukcji sprawy na 
jaw wyjdą dowody stwierdzające „oczywistą nieważność” i spełniona zostanie przesłanka z nowego dokumentu, czyli zgodność stron.

Po burzliwej dyskusji ogłoszono przerwę w obradach i goście udali się na przerwę kawową w celu regeneracji sił fizycznych i umysłowych przed kolejną sesją konferencji.

Drugiej sesji przewodniczył Wikariusz Sądowy Biskupa Płockiego ks. dr Tadeusz Kozłowski, który zaprosił do stołu prezydialnego prelegentów. Pierwszy wykład wygłosiła prof. KUL dr hab. Marta Greszata-Telusiewicz, w którym wyjaśniła zasady budzącego największe emocje w dyskusji procesus brevior. Pani Profesor wskazała istotną rolę oficjała w wyborze trybu procedowania oraz omówiła przesłankę, jaką przypadek musi spełniać ex lege przy dowodzeniu nieważności małżeństwa $\mathrm{w}$ procesie skróconym przed biskupem diecezjalnym. Jest nią, zgodnie z dokumentem papieża Franciszka: zgodna prośba małżonków o zbadanie ważności ich małżeństwa oraz dowody wskazujące na oczywistą jego nieważność. Pani Profesor w interesujący sposób zauważyła problem apelacji w procesie skróconym sugerując, że została ona utrzymana tylko ze względu na szacunek dla starej kodeksowej zasady procesowej. Zauważyła bowiem, że w praktyce apelacja od wyroku biskupa będzie rzadkością, a jedynym podmiotem zdolnym do apelacji od orzeczenia biskupa diecezjalnego będzie obrońca węzła.

Następnie głos zabrał ks. prof. KUL dr hab. Leszek Adamowicz, który zmienił temat swojego wystąpienia, zaznaczając, że przygotowany przez niego referat pod tytułem „Okoliczności osób i rzeczy zezwalające na prowadzenie procesu skróconego” zostanie wydrukowany w publikacji pokonferencyjnej. Interesującym, zdaniem ks. Adamowicza, było przytoczenie odpowiedzi Sygnatury Apostolskiej, które napłynęły w kwestiach budzących wiele wątpliwości. Ksiądz Profesor analizując wypowiedzi najwyższego watykańskiego Trybunału przytoczył następującą wykładnię: wikariusz może wydać dekret wykonawczy w procesie małżeńskim, oficjał jest odpowiedzialny za wybór trybu postępowania w sprawie o nieważność małżeństwa, metropolita nim odrzuci apelację musi wysłuchać opinii stron oraz obrońcy węzła. Co więcej Sygnatura wskazuje, że każdy biskup musi ustanowić 
wikariusza sądowego i obrońcę węzła małżeńskiego. Profesor Adamowicz w związku z powyższym zauważył, że w Polsce konieczne jest ustanowienie tych urzędów między innymi w Ordynariacie Polowym. Ponadto, prelegent przedstawił postanowienia Rady Prawnej Konferencji Episkopatu Polski, która wydała wstępną rekomendację do wydania norm dla wszystkich polskich oficjałów wskazującą, że wydanie zgody na udział w procesie adwokata ad casum uzależnione jest od zatwierdzenia adwokata na stałe przy innym sądzie.

„Pewność moralna w procesie skróconym i zwyczajnym” była tematem referatu ks. prof. dr. hab. Gintera Dzierżona z UKSW w Warszawie. Słynny kanonista mocno podkreślił, że dokument Ojca Świętego Franciszka nie przedstawia w żaden sposób nowej koncepcji pewności moralnej. Przytoczył wytyczne wyrażone w przemówieniach do Roty Rzymskiej następców św. Piotra: Piusa XII z 1942 roku oraz Jana Pawła II z 1980 roku. Nowość wprowadzona przez motu proprio Mitis Iudex Dominus Iesus w materii pewności moralnej polega na szybszym jej uzyskaniu, szczególnie biorąc pod uwagę osobę biskupa pojmowaną jako iudex natus oraz oczywistość przedmiotu poznania. Profesor Dzierżon wysunął postulat, że proces w trybie skróconym powinien być stosowany „niezwykle rzadko”, ze względu na to, że oczywistość nieważności małżeństwa występuje sporadycznie.

Ostatnim wystąpieniem w drugiej sesji, a jednocześnie zamykającym całe obrady, był referat ks. prof. dr hab. Ryszarda Sztychmilera z Uniwersytetu Warmińsko-Mazurskiego w Olsztynie, traktujący o „Posłudze adwokata po Mitis Iudex”. Ksiądz Profesor podkreślił, że reforma „franciszkańska” przy pierwszej analizie jawi się jako niewielka, jest ona jednak „poważną reformą kanonicznych procesów o stwierdzenie nieważności małżeństwa”. Ponadto, prelegent zaznaczył, że rola adwokata w odnowionym procesie jest większa niż za czasów poprzednich regulacji prawnych. Konieczna jest zatem, zdaniem Księdza Sztychmilera, odpowiednia formacja (przygotowanie) nie tylko adwokatów, ale i wiernych będących potencjalnymi klientami sądów. Profesor z Olsztyna zakończył: „Sądzę, że trzeba 
będzie wiele wysiłków (...), aby postawione przez Franciszka cele dało się dobrze zrealizować, by uniknąć zgorszenia”.

Przystąpiono do dyskusji, w której jako pierwszy głos zabrał ks. prof. dr hab. Wojciech Góralski, kierując swoje słynne ad vocem do referatu ks. prof. dr. hab. Gintera Dzierżona, stwierdzając, że do orzeczenia nieważności małżeństwa nie jest konieczne posiadanie przez sędziego pewności absolutnej. Podkreślił także, że pewność moralna jest jedna, różne mogą być jednak drogi do jej poznania. Ponadto przytoczył twierdzenie o. prof. dr. hab. Jacka Salija, który słusznie twierdzi, że wiara nie jest konieczna do zaistnienia sakramentu.

Głos zabrał także ks. prof. UKSW dr hab. Józef Wroceński, wieloletni Dziekan Wydziału Prawa Kanonicznego UKSW w Warszawie, który postawił dwa pytania: „Czy istnieją inne okoliczności, które sugerują oficjałowi skierowanie sprawy na tryb skrócony?” oraz „Skoro prawodawca ustanawia nowy tryb procesu, to dlaczego nauka prawa kanonicznego stawia postulat, aby wykorzystywać go „rzadko”?” Profesor Wroceński zauważył także, że to prawodawca widzi ratio legis wprowadzenia danych norm i należy jej stosować zawsze, a nie tylko w określonych sytuacjach. Na pierwsze pytanie Księdza Dziekana odpowiedział ks. Adamowicz, który stwierdził, że nie istnieją inne okoliczności pozwalające na skierowanie sprawy do procesu skróconego, a normy zawarte w motu proprio papieża Franciszka stanowią katalog zamknięty. Do drugiego pytania ks. Wroceńskiego odniósł się ks. Dzierżon, który pogłębił myśl wyrażoną w swoim wystąpieniu stwierdzeniem: „nie tylko rzadko, ale bardzo rzadko”. Profesor Dzierżon podkreślił, że logiczne jest istnienie prawa, a co za tym idzie jego egzekwowanie, jednak w badaniu ratio legis ustaw konieczne jest zrozumienie „dlaczego tak jest”. Zdaniem znanego kanonisty, nie chodzi o intuicję prawną, lecz o stałość zarówno prawodawcy, jak i tych, którzy prawo stosują, z okiem szeroko otwartym na dobro dusz.

Konferencję zakończył ks. prof. dr hab. Wojciech Góralski, współorganizator wydarzenia oraz jeden z najwybitniejszych przedstawicieli polskiej szkoły kanonistyki. Podziękował wszystkim prelegentom i uczestnikom za przybycie, wskazując szczególną radość 
organizatorów za obecność świeckich „coraz częściej przyjmowanych do trybunałów kościelnych”. Podkreślił, że myśl zorganizowania konferencji w popowskim ośrodku Caritas znalazła pełne zrozumienie i wsparcie ze strony ks. bp. dr. Piotra Libery, ordynariusza płockiego. Szczególne podziękowania skierowane zostały do ks. abpa Andrzeja Dzięgi, który „łaskawie przyjął propozycję wygłoszenia referatu”. Ksiądz Góralski wyraził także wdzięczność gościom z zagranicy na czele z biskupem pińskim Antonim Dziemianko. Na zakończenie raz jeszcze podziękowano wszystkim obecnym, a ks. Jan Krajczyński wraz z ks. Wojciechem Góralskim życzyli wszystkim bezpiecznego powrotu do domów, pomyślności we wcielaniu w życie postanowień motu proprio papieża Franciszka oraz dobrego obiadu.

Igor Kilanowski 